\author{
Joanna Dyczkowska \\ Uniwersytet Ekonomiczny we Wrocławiu \\ e-mail: joanna.dyczkowska@ue.wroc.pl \\ ORCID: 0000-0001-9070-5116
}

\title{
ZASADA ISTOTNOŚCI W RAPORTOWANIU NIEFINANSOWYM
}

\section{MATERIALITY PRINCIPLE IN NON-FINANCIAL REPORTING}

DOI: $10.15611 / \mathrm{pn} .2019 .544 .13$

JEL Classification: M14, M41

Streszczenie: Celem głównym artykułu jest porównanie podejść do zasady istotności ujawnień na gruncie raportowania CSR, zrównoważonego rozwoju i zintegrowanego, a także wyjaśnienie relacji zasady istotności z pozostałymi zasadami stanowiącymi podstawę dobrych praktyk w obszarze raportowania niefinansowego. Artykuł nawiązuje do metodyk procesu określania istotności wskazanych w wytycznych GRI, standardach AA1000 oraz rekomendacjach IFAC. Poruszany temat przedstawia istniejące rozwiązania oraz nawiązuje do wprowadzonych ostatnio zmian lub poprawek. W publikacji zaprezentowano też wnioski wynikające $\mathrm{z}$ dokumentu dotyczącego zmian w definiowaniu istotności w odniesieniu do sprawozdań finansowych, opublikowanego przez IASB w październiku 2018 r., oraz wznowionego standardu AA1000 AP dotyczącego zasad społecznej odpowiedzialności biznesu. Przeprowadzone w artykule wnioskowanie utwierdza czytelnika w przekonaniu, że sprawozdawczość niefinansowa ukierunkowana jest na potrzeby szerokiego grona interesariuszy.

Słowa kluczowe: AA1000, CSR, GRI, informacje niefinansowe, raportowanie zintegrowane, zasada istotności, zrównoważony rozwój.

Summary: The main objective of the paper is to compare approaches to the materiality principle with regard to reporting on CSR and sustainable development as well as integrated reporting. The article also explains the relation of the materiality principle to other principles that form the basis of good practices in the non-financial reporting area. It highlights the methodologies of the materiality determination process indicated in the GRI guidelines, AA1000 standards and IFAC recommendations. The presented topic refers to existing solutions and adresseses recent changes or amendments. The publication presents conclusions resulting from the document on changes in defining materiality in relation to financial statements published by the IASB in October 2018 and the renewed standard AA1000 AP. The inferences confirm the reader in the belief that non-financial reporting is targeted at the needs of a wide range of stakeholders.

Keywords: AA1000, CSR, GRI, non-financial information, integrated reporting, materiality principle, sustainable development. 


\section{Wstęp}

Istotność informacji ujawnianych w sprawozdaniach finansowych była wielokrotnie definiowana i doskonalona zarówno w międzynarodowych standardach rachunkowości (MSR), jak i międzynarodowych standardach sprawozdawczości finansowej (MSSF), w wytycznych Globalnej Inicjatywy Sprawozdawczej (GRI - Global Reporting Initiative), w międzynarodowych standardach społecznej odpowiedzialności biznesu AA1000, a także w rekomendacjach odnoszących się do kwestii istotności informacji w raportowaniu zintegrowanym, opracowanych przez Międzynarodową Federację Księgowych (IFAC - International Federation of Accountants)'1. Celem głównym tego artykułu jest porównanie podejść do zasady istotności ujawnień na gruncie raportowania CSR, zrównoważonego rozwoju i zintegrowanego, a także wyjaśnienie relacji zasady istotności z pozostałymi zasadami stanowiącymi podstawę dobrych praktyk w obszarze raportowania niefinansowego. Artykuł nawiązuje również do metodyk procesu określania istotności wskazanych w wytycznych GRI, standardach AA1000 oraz rekomendacjach IFAC. W artykule przedstawiono istniejące rozwiązania oraz nawiązano do wprowadzonych ostatnio zmian lub poprawek. $\mathrm{W}$ publikacji tej zaprezentowano wnioski wynikające $\mathrm{z}$ dokumentu dotyczącego zmian w definiowaniu istotności, opublikowanego przez IASB pod koniec października 2018 r., oraz wznowionego standardu AA1000 AP dotyczącego zasad społecznej odpowiedzialności biznesu, który został wydany w 2018 r.

\section{Ujęcie kwestii istotności ujawnianych informacji w MSSF i MSR}

Istotność informacji ujawnianych w sprawozdaniach finansowych została zdefiniowana zarówno w międzynarodowych standardach rachunkowości, jak i ujęta w ramach koncepcyjnych MSSF. Przez dłuższy czas obowiązywała definicja mówiąca o istotnych pominięciach lub zniekształceniach, które indywidualnie lub zbiorowo mogą wpływać na decyzje gospodarcze podejmowane na podstawie sprawozdania finansowego przez użytkowników raportów (w tym przypadku głównie inwestorów) [MSR 1 i MSR 8]. MSR 1 zwraca uwagę na to, że istotność informacji będzie uzależniona od wielkości i rodzaju pominięcia lub zniekształcenia w kontekście towarzyszących okoliczności. Z kolei to, czy rzeczywiście pominięcie lub zniekształ-

\footnotetext{
${ }^{1}$ Ponadto swoją definicję istotności formułowały również takie instytucje, jak: Amerykańska Komisja Papierów Wartościowych i Giełd (SEC - US Securities and Exchange Commission), Rada Raportowania Finansowego (FRC - Financial Reporting Council), Rada ds. Standardów Zrównoważonej Rachunkowości (SASB - Sustainability Accounting Standards Board), Rada ds. Standardów Ujawniania Informacji Dotyczących Klimatu (CDSB - Climate Disclosure Standards Board) oraz Międzynarodowa Organizacja Normalizacyjna (ISO - The International Organization for Standardization) (zob. szerzej: [CDP, CDSB, GRI, IFRS, IR, ISO, SASB 2016]).
} 
cenie informacji wpłynie na decyzje gospodarcze, będzie zależało od cech adresatów raportów. Oczekuje się bowiem, że użytkownicy sprawozdań z reguły posiadają dostateczną wiedzę ekonomiczną oraz wykazują chęć uważnego zapoznania się z prezentowanymi informacjami. Ramy koncepcyjne MSSF powielają stanowisko zawarte w MSR 1 i MSR 8 w odniesieniu definicji kwestii istotności informacji.

Warto zwrócić uwagę, że IASB wydała w 2015 r. raport (ED/2015/8), w którym zasygnalizowała potrzebę zmian omawianej definicji. Rada zasugerowała, aby zastanowić się nad trzema aspektami: nieprzejrzystością informacyjną (information obscurity), uzasadnionymi oczekiwaniami w zakresie wpływu informacji na decyzje użytkowników, głównymi adresatami sprawozdań finansowych. IASB zwróciła ponadto uwagę, że zaciemnianie istotnych informacji może mieć podobny skutek jak ich pominięcie, dlatego w definicji istotności należy wziąć pod uwagę nieprzejrzystość informacyjną. Obecny termin „może wpływać” jest szeroki i oznacza uwzględnienie zbyt dużej ilości informacji, co może negatywnie oddziaływać na decyzje podejmowane przez użytkowników. W związku z powyższym IASB zarekomendowała skoncentrowanie się wyłącznie na tych informacjach, które racjonalnie mogą przyczynić się do zmian decyzji przez inwestorów. W końcu Rada zasygnalizowała, że termin , użytkownicy” był nieprecyzyjny i mógł wskazywać na wszystkich potencjalnych odbiorców sprawozdań finansowych. Mogło to powodować, że ponownie zbyt wiele nieistotnych informacji byłoby ujawnianych w celu zaspokojenia potrzeb szerokiej grupy użytkowników. Aby zaradzić tym problemom, IASB wydała nową interpretację terminu istotności ujawnianych informacji [IASB 2018a]. Została ona wprowadzona do MSR 1 i MSR 8 oraz dostosowana do definicji ujętej w ramach koncepcyjnych MSSF. Nowe brzmienie definicji istotności, która będzie obowiązywać dla okresów sprawozdawczych rozpoczynających się 1 stycznia 2020 r. lub po tej dacie, jest następujące:

„Informacje są istotne, jeżeli można racjonalnie oczekiwać, że ich pominięcie, zniekształcenie lub zaciemnienie ma wpływ na decyzje, które główni użytkownicy raportów podejmują na podstawie sprawozdań dostarczających informacji finansowych o konkretnej jednostce raportującej”.

Należy zauważyć, że istotność informacji w ujęciu zaprezentowanym przez IASB jest określana w kontekście ich ważności dla inwestorów oraz pozostałych użytkowników informacji finansowych. Część OB2 ram koncepcyjnych MSSF wskazuje, że obecni i potencjalni inwestorzy, kredytodawcy oraz inni wierzyciele są głównymi użytkownikami sprawozdawczości finansowej ogólnego przeznaczenia. Wykorzystują oni informacje finansowe do podejmowania decyzji dotyczących zakupu, sprzedaży lub posiadania instrumentów kapitałowych lub dłużnych oraz udzielania lub rozliczania pożyczek lub innych form kredytu. W literaturze przedmiotu podkreśla się ponadto, że informacje płynące $\mathrm{z}$ rachunkowości, zaprezentowane w raportach zawierających dobrowolne ujawnienia, mogą służyć jako narzędzie niwelowania asymetrii informacji pomiędzy właścicielami (pryncypałami) a menedżerami 
(agentami), co ma szczególne znaczenie w sytuacji, gdy własność jest oddzielona od zarządzania [Dobija 2010; Gruszecki 2002]. W świetle ram koncepcyjnych MSSF pozostali interesariusze, $\mathrm{tj}$. pracownicy, klienci, dostawcy oraz szeroko pojmowane społeczeństwo, nie są uważani za głównych użytkowników, w związku z tym sprawozdania finansowe ogólnego przeznaczenia nie są kształtowane priorytetowo pod kątem ich oczekiwań. MSR-y i MSSF-y nie wymagają też sporządzania sprawozdania z działalności spółki, co wpływa automatycznie na mniejszy zakres ujawnień narracyjnych o charakterze niefinansowym.

Naprzeciw oczekiwaniom szeroko pojmowanych interesariuszy wychodzą wytyczne GRI oraz międzynarodowe standardy społecznej odpowiedzialności biznesu AA1000. Jest to związane z potrzebą legitymizowania coraz bardziej złożonej działalności przedsiębiorstw oraz jej ekonomicznych, społecznych i środowiskowych efektów. Pojęcie interesariuszy pojawiło się w literaturze dotyczącej obszaru zarządzania w latach 60. ubiegłego wieku w wewnętrznym memorandum Instytutu Badawczego Stanforda (Stanford Research Institute). Celem wprowadzenia nowego terminu była chęć uogólnienia dotychczasowego wąskiego podejścia do grupy zainteresowanej wynikami spółek - jaką w uprzednim przekonaniu tworzyli dawcy kapitału finansowego. Dlatego nowa idea określiła interesariuszy jako te grupy, bez których wsparcia organizacja przestałaby istnieć [Freeman i in. 2010]. Istnieją co najmniej cztery typy koncepcji interesariuszy, które integrują się z teoriami różnych dyscyplin pochodzących z dziedzin nauk społecznych, są to koncepcje: empiryczna $^{2}$, instrumentalna ${ }^{3}$, normatywna ${ }^{4}$ oraz metaforyczna ${ }^{5}$ [Andriof, Waddock 2002, za: Marcinkowska 2011]. Płynne przenikanie koncepcji interesariuszy z teoriami różnych dyscyplin wskazuje na jej uniwersalność.

${ }^{2} \mathrm{~W}$ podejściu empirycznym przyjmuje się założenie, że organizacje i/lub menedżerowie zachowują się w określony sposób. W celu wyjaśnienia tych zachowań nawiązuje się w przypadku menedżerów do koncepcji psychologicznych i socjologicznych (np. tzw. menedżeryzmu), a w przypadku organizacji do teorii organizacji i teorii decyzji (por. [Marcinkowska 2011, s. 857]).

${ }^{3} \mathrm{~W}$ podejściu instrumentalnym przyjmuje się założenie, że organizacje/menedżerowie osiągną zamierzone efekty z większym prawdopodobieństwem, jeżeli będą postępować w określony sposób. W celu wyjaśnienia ich postępowania nawiązuje się do teorii sieci społecznych lub teorii kosztów transakcyjnych (por. [Marcinkowska 2011, s. 857]).

${ }^{4} \mathrm{~W}$ podejściu normatywnym przyjmuje się założenie, że organizacje/menedżerowie powinni postępować w ściśle określony sposób, zgodnie z przyjętymi normami. W celu wyjaśnienia ich postępowania nawiązuje się w przypadku zasad zorientowanych na system do teorii utylitaryzmu, libertarianizmu lub kontraktów społecznych, a w przypadku zasad zorientowanych na organizację - do teorii agenta-pryncypała (por. [Marcinkowska 2011, s. 857]).

${ }^{5} \mathrm{~W}$ podejściu metaforycznym tworzone są metafory opisujące, w jaki sposób interesariusze generują i wymieniają wartość. W celu wyjaśnienia tych procesów, zamiast wysublimowanego konstruktu teoretycznego, tworzona jest narracja, która opisuje cały proces tworzenia i wymiany wartości, w którym to podmiotami badań są uczestnicy procesów organizacyjnych (por. [Marcinkowska 2011, s. 857]). 


\section{Rozwój pojęcia istotności ujawnianych informacji w wytycznych GRI}

Wytyczne GRI od momentu, kiedy się ukazały (1997 r.), stanowiły przez długi okres podstawę odniesienia dla podmiotów przygotowujących raporty w zakresie zrównoważonego rozwoju. Opublikowano kilka wersji wytycznych, w tym: GRI 2000, GRI G2, GRI G3, GRI G3.1 oraz GRI G4. Ostatnie z tych wytycznych przestały obowiązywać po 1 lipca 2018 r. W to miejsce wszedł zestaw standardów GRI składający się z trzech uniwersalnych standardów, obejmujących: GRI 101 (Podstawowe Założenia), GRI 102 (Ogólne Ujawnienia), GRI 103 (Podejście Zarządcze) oraz trzech serii standardów odnoszących się do kwestii ujawnień w obszarach: ekonomicznym (GRI 200), środowiskowym (GRI 300) i społecznym (GRI 400) [GRI 2016]. Zestaw standardów GRI ma zastosowanie do raportów sporządzanych odnośnie do roku 2016 oraz kolejnych lat. Inicjatywa GRI stanowi podstawę raportowania ukierunkowanego na interesariuszy, a jej kolejne wytyczne są wyrazem ich nieustannego angażowania w powtarzalny proces definiowania potrzeb informacyjnych oraz oczekiwań względem ujawnianych informacji niefinansowych.

S. Zadek i M. Merme [2003] wskazują, że wytyczne GRI mają jednak jedną wadę $\mathrm{w}$ odniesieniu do ustalania istotności informacji, która polega na tym, że nie wskazują, co jest istotne w określonych okolicznościach. W literaturze zwraca się uwagę, że istotność kwestii ujawnianych jest specyficzna dla określonych jednostek. FRC [2012] akcentuje, że o ile problem rozpoznania i pomiaru kwestii istotnych jest dobrze ukonstytuowany, co odzwierciedla się w przyjętych zasadach, o tyle istotność informacji z perspektywy konieczności ich ujawnień nie jest jasna i polega zwykle na przestrzeganiu zakresu ujawnień obowiązkowych określonych w przyjętych standardach rachunkowości lub w propozycjach ujawnień dobrowolnych, rekomendowanych przez różne instytucje.

Zmiany w pojęciu istotności można zaobserwować na przykładzie przemian w jej definiowaniu w kolejnych rekomendacjach GRI. W wytycznych GRI G2 [2002], istotność, a w zasadzie trafność ujawnień (relevance) była przedstawiana jako stopień ważności przypisany do konkretnego aspektu, wskaźnika lub fragmentu informacji, który stanowił zarazem uzasadniony próg, przy którym informacja stawała się wystarczająco istotna, aby można było ją ujawnić w raporcie. Dodatkowo zasada kompletności mówiła o tym, że wszystkie informacje, które są istotne dla użytkowników raportu, powinny pojawić się w nim w sposób zgodny z zadeklarowanymi granicami, zakresem tematycznym oraz wymiarem czasowym. Oczekiwano, że granice raportowania będą definiowane w kontekście ekonomicznego, środowiskowego i społecznego wpływu organizacji na otoczenie z uwzględnieniem własności prawnej, relacji biznesowych oraz innych czynników, a także zakresu, jaki obejmuje kontrola finansowa podmiotu.

Cztery lata później kolejne opublikowane wytyczne GRI G3 [2006] zredefiniowały pojęcie istotności informacji, dodając, co oznacza ona dla użytkowników ra- 
portu. Podkreślono, że informacje są istotne, gdy znacząco wpływają na decyzje i oceny dokonywane przez interesariuszy. Ponadto w wytycznych zawarto dość obszerne wyjaśnienia dotyczące wewnętrznych i zewnętrznych czynników, które powinny być brane pod uwagę przy określeniu istotności informacji. Zaakcentowano również potrzebę nadania priorytetów istotnym aspektom oraz wskaźnikom z nimi związanym. W wytycznych GRI G3 po raz pierwszy dokonano graficznej prezentacji istotnych aspektów w postaci macierzy istotności, gdzie jednym z wymiarów był wpływ istotnych kwestii na ocenę i decyzje podejmowane przez interesariuszy, natomiast drugim - znaczenie ekonomicznych, środowiskowych i społecznych wpływów działalności. Co więcej dokonano rozróżnienia pomiędzy dwiema grupami zasad odnoszących się do dobrowolnych ujawnień. Pierwsza z nich definiowała dobre praktyki w obszarze kształtowania zawartości raportu, natomiast druga dotyczyła zapewnienia cech jakościowych raportu (tab. 1).

Istotność jest jedną z czterech zasad odnoszących się do wymogów dotyczących zawartości raportu zrównoważonego rozwoju. Realizacja tej zasady polega na określeniu i ujawnieniu kluczowych aspektów, które stanowią manifestację istotnego wpływu ekonomicznego, środowiskowego i społecznego organizacji na otoczenie. Ponadto przyjmuje się, że aspekty te w sposób rzeczowy wpływają na oceny i decyzje podejmowane przez interesariuszy [GRI 2013a, s. 17]. Skupienie się na istotności informacji ma sprawić, że raporty zrównoważonego rozwoju będą bardziej trafne, wiarygodne i zgodne z oczekiwaniami ich użytkowników. To z kolei pozwoli na lepsze informowanie rynków i społeczeństwa o ekonomicznych, środowiskowych i społecznych efektach, jakie generuje organizacja na skutek swoich działań biznesowych.

Proces definiowania istotnych aspektów oraz ich granic według wytycznych GRI G4 [2013b] został zaprezentowany na rys. 1. Składa się on z trzech etapów poprzedzających dokonanie ujawnień w raporcie zrównoważonego rozwoju, a obejmujących:

1) identyfikację aspektów o istotnym oddziaływaniu;

2) priorytetyzację aspektów o istotnym oddziaływaniu;

3) zatwierdzenie zbilansowanej reprezentacji aspektów o istotnym oddziaływaniu.

Aspekty istotne powinny podlegać okresowym przeglądom oraz uwzględniać oczekiwania interesariuszy i kontekst ich wagi dla zrównoważonego rozwoju.

Należy zwrócić uwagę, iż wytyczne GRI G4 umiejscowiły kwestię istotności ujawnianych informacji w centrum praktyk raportowania. KPMG [2013] podkreśla, że rekomendacje GRI G4 wymagają od organizacji raportujących skupienia na istotnych aspektach w całym tekście raportu. Ponadto oczekuje się, że organizacje w szczegółowy sposób odniosą się do sposobu, w jaki zarządzają istotnymi aspektami (disclosures on management approach). Dodatkowo raporty muszą określić granice poszczególnych wpływów, jakie organizacje wywierają na otoczenie. W końcu organizacje powinny udzielić informacji odnośnie do procesu, przez jaki przecho- 
Tabela 1. Zasady dotyczące dobrowolnych ujawnień w kontekście zawartości i jakości raportu

\begin{tabular}{|c|c|}
\hline Zasady odnoszące się do zawartości raportu & Zasady odnoszące się do jakości raportu \\
\hline 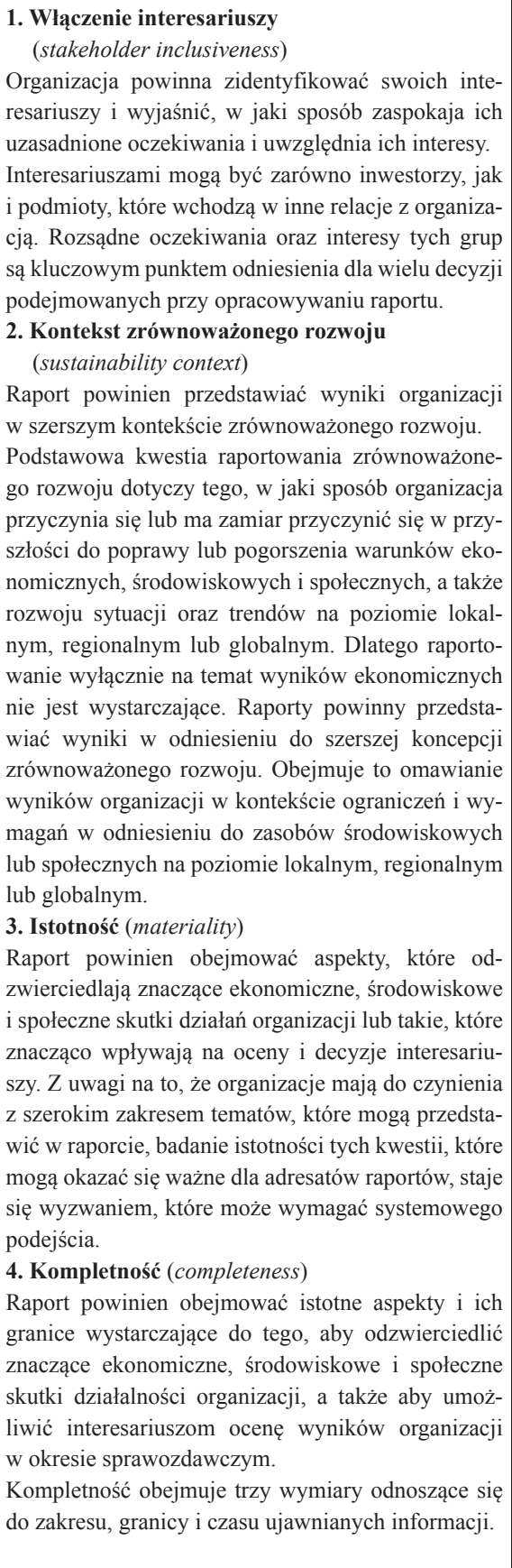 & 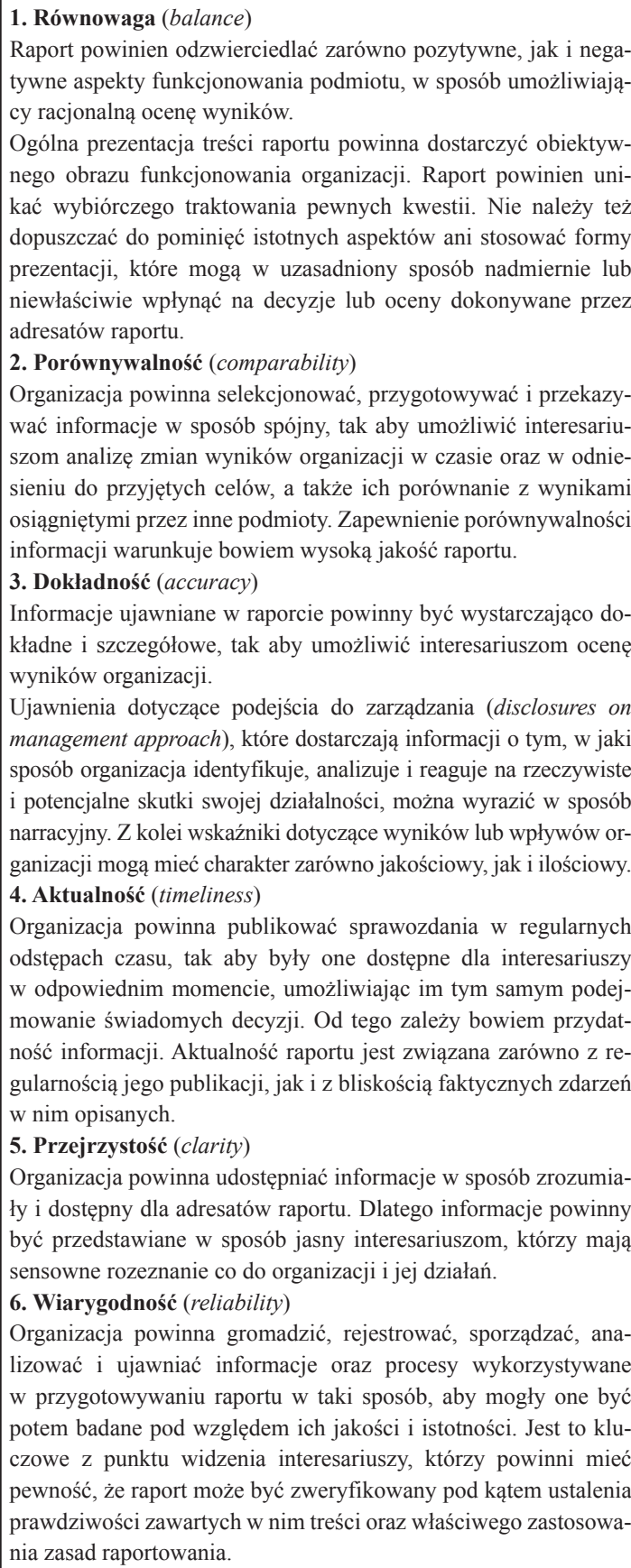 \\
\hline
\end{tabular}

Źródło: opracowanie na podstawie [GRI 2006; GRI 2011; GRI 2013a]. 


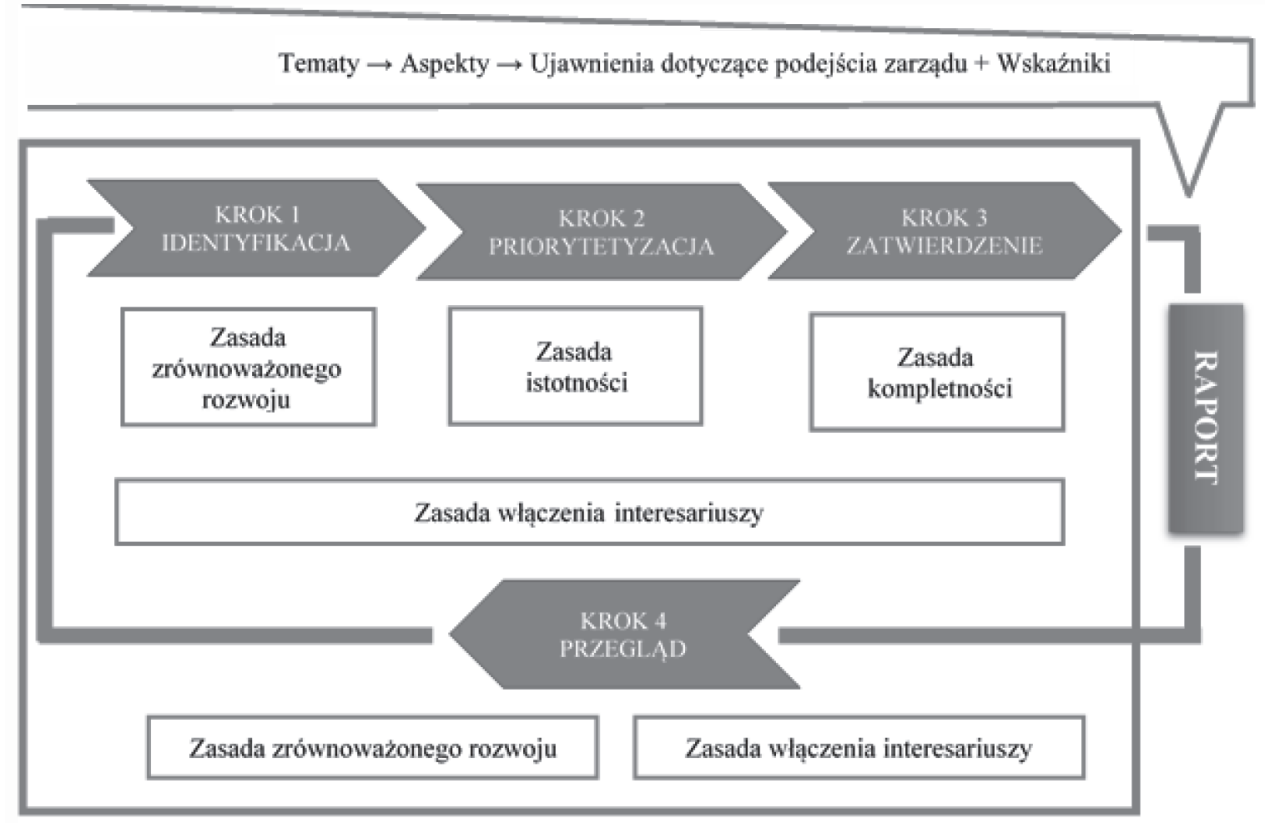

Rys. 1. Proces definiowania istotnych aspektów i ich granic

Źródło: [GRI 2013b, s. 32].

dzą, aby określić ich istotne aspekty, a także ryzyka oraz szanse. Należy również opisać zaangażowanie interesariuszy w ten proces [KPMG 2013, s. 3].

W nowych standardach GRI [2016] nie zmieniło się ujęcie zasady istotności, wyjaśniono natomiast terminy dotyczące wpływu oraz jego dwóch wymiarów. Podkreślono, iż stosowany termin „wpływ” należy rozumieć jako siłę oddziaływania na otoczenie ekonomiczne, środowiskowe oraz społeczne organizacji, a nie na przedsiębiorstwo samo w sobie. Zwrócono też uwagę, że wpływ na otoczenie to tylko jeden z wymiarów, który należy brać pod uwagę przy określaniu istotności ujawnianych kwestii. Drugim wymiarem jest znaczenie tych kwestii dla interesariuszy. Zaakcentowano, że dany aspekt może być uznany za istotny, jeżeli ma wysoki wpływ tylko na jeden $\mathrm{z}$ wymiarów.

Na podanym przykładzie wyraźnie widać zupełnie inny kierunek idei raportowania niż w przypadku ram koncepcyjnych MSSF. Uwypukla on rolę, jaką w całym procesie raportowania pełnią zarządzający. Wytyczne GRI oferują również zupełnie inne podejście do tego, komu służyć mają przygotowywane przez organizacje raporty. W przeciwieństwie do ram koncepcyjnych MSSF, które jako głównych adresatów sprawozdawczości wskazują użytkowników informacji finansowych, tutaj w centrum zainteresowania jest szerokie grono interesariuszy. 


\section{Międzynarodowe standardy społecznej odpowiedzialności biznesu AA1000}

Międzynarodowe standardy społecznej odpowiedzialności biznesu AA1000 składają się z kilku dokumentów, które były regularnie doskonalone, aktualizowane i rozszerzane. Pierwszy standard, zawierający zasady dotyczące odpowiedzialności za zrównoważony rozwój, został opublikowany w 1999 roku.

Cztery lata później opublikowano pierwszą edycję standardu AA1000 AS (2003), dotyczącego zapewnienia wiarygodności i jakości wyników w zakresie zrównoważonego rozwoju i sprawozdawczości. Również i ten standard został wznowiony w 2008 r. Jego celem było wsparcie praktyków i instytucji oceniających zgodność przestrzegania dobrych praktyk w zakresie zrównoważonego rozwoju przez organizacje raportujące oraz wskazanie, w jaki sposób powinna być oceniana jakość publicznie ujawnianych informacji na temat wyników niefinansowych.

Omawiany standard jest nierozerwalnie związany z zasadami odpowiedzialności za zrównoważony rozwój, które początkowo były ujęte w AA1000 AS (2003), natomiast w 2008 r. zostały zawarte w osobnym dokumencie - AA1000 APS (2008). Wstępnie zestaw omawianych reguł odpowiedzialności za zrównoważony rozwój obejmował zasadę włączenia interesariuszy (inclusivity principle), zasadę istotności (materiality principle) oraz wrażliwości i otwartości na współpracę (responsiveness principle).

W najnowszej edycji AA1000 AP [2018] trzy powyższe reguły zostały uzupełnione o zasadę wpływu (impact principle). Wpływ jest definiowany jako efekt zachowań, dokonań i/lub wyników jednostek lub organizacji, który oddziałuje na gospodarkę, środowisko, społeczeństwo, interesariuszy lub na samą organizację. Zasada wpływu mówi o tym, że organizacje powinny monitorować oraz dokonywać pomiaru efektów swojej działalności, a także stać się odpowiedzialnymi za to, jak ich działania wpływają na szerszy ekosystem. Z kolei zasada istotności według standardów AA1000 AP [2018] mówi o tym, że zarządzający powinni identyfikować oraz mieć pewność co do znaczenia aspektów zrównoważonego rozwoju dla organizacji i jej interesariuszy. Kolejnym krokiem jest dokonanie ich priorytetyzacji. Istotne aspekty to takie, które będą znacząco wpływać na oceny, decyzje, działania i dokonania organizacji i/lub jej interesariuszy w perspektywie krótko-, średnioi długoterminowej.

W celu prawidłowego zastosowania zasady istotności oraz monitorowania jej realizacji organizacja powinna spełnić pewne kryteria, które po pierwsze, odzwierciedlają dążenie organizacji w kierunku integracji i budowania potencjału umożliwiającego [AA1000 AP 2018, s. 22]:

- stworzenie solidnego, systematycznego i ciągłego procesu określania istotności, który będzie prowadzony pod nadzorem kierownictwa wyższego szczebla z uwzględnieniem zaangażowania osób z różnych działów; 
- zapewnienie integracji procesu oceny istotności ujawnianych kwestii w całej organizacji, w tym poprzez odpowiednie procesy, zgodność z przepisami ustawowymi i wykonawczymi oraz wewnętrznymi zasadami i procedurami;

- zagwarantowanie kompetencji i zasobów niezbędnych do zastosowania wyników procesu oceny istotności.

Po drugie, oczekuje się, że w zakresie samego procesu określania istotności zostaną:

- ustalone spójne i jasne granice raportowania, jak również cel, okres i zakres sprawozdawczości z uwzględnieniem odpowiednich założeń;

- zidentyfikowane i rzetelnie zaprezentowane aspekty mające różne źródła;

- ocenione znaczenia zidentyfikowanych aspektów dotyczących zrównoważonego rozwoju w oparciu o odpowiednie i jednoznaczne kryteria, które są jasne, zrozumiałe, uzasadnione i możliwe do wielokrotnego zastosowania;

- określone istotność, prawdopodobieństwo oraz obecny i przewidywany wpływ zidentyfikowanych aspektów w oparciu o odpowiednie kryteria i progi;

- uwzględnione zmieniające się warunki dla zrównoważonego rozwoju, w tym czynniki makroekonomiczne, geopolityczne i regulacyjne oraz dojrzałość tematów i problemów, umożliwiające uwzględnienie różnic branżowych, geograficznych, kulturowych i oraz tych powstających na poziomie operacyjnym;

- określone metody rozwiązywania konfliktów lub dylematów wynikających z rozbieżnych lub sprzecznych oczekiwań dotyczących tego, co jest istotnym dla organizacji i jej interesariuszy tematem.

Po trzecie, podkreśla się rolę komunikacji w całym procesie określania istotności. Polega ona na tworzeniu, a następnie ujawnianiu zbilansowanego, ale kompleksowego rozumienia oraz priorytetyzacji istotnych dla zrównoważonego rozwoju kwestii z punktu widzenia organizacji i jej interesariuszy. Może to być zagwarantowane poprzez realizację kolejnej z zasad, dotyczącej wrażliwości i otwartości na współpracę (responsiveness principle). Reguła ta mówi o terminowej i odpowiedniej reakcji organizacji na istotne dla zrównoważonego rozwoju aspekty oraz o rozważeniu ich wpływów na otoczenie. Reakcja ta powinna mieć swoje odzwierciedlenie w podejmowanych decyzjach i działaniach oraz osiągniętych wynikach. Oczekuje się ponadto, że organizacja będzie utrzymywała ciągłą komunikację z interesariuszami, w sposób odpowiadający ich potrzebom i oczekiwaniom, a raportowanie będzie odbywało się w sposób kompleksowy, dokładny, terminowy, dostępny i wyważony, z wykorzystaniem stosownych zasad, ram i wytycznych raportowania, które mają zapewnić porównywalność informacji [AA1000 AP 2018, s. 25].

\section{Wytyczne dotyczące kwestii istotności informacji w raportowaniu zintegrowanym}

Tematowi określania istotności kwestii ujawnianych $\mathrm{w}$ raportach zintegrowanych został poświęcony cały rozdział zawierający wytyczne dotyczące przygotowywania raportów zintegrowanych opracowanych przez IFAC [2015]. Wytyczne definiu- 
ją pojęcie istotności oraz wyjaśniają przebieg procesu prowadzącego do ustalenia, które aspekty powinny zostać ujawnione w raporcie zintegrowanym. W kontekście raportowania zintegrowanego ujawniona kwestia jest istotna, jeżeli faktycznie wpływa ona na zdolność organizacji do kreowania wartości w krótkim, średnim oraz długim okresie. Interesującym wskazaniem jest to, że proces określania istotności kwestii, które zostaną ujawnione, będzie specyficzny dla każdej organizacji oraz uzależniony od sektora, w jakim ona działa, oraz od innych czynników. Zaleca się przy tym przyjęcie podejścia, które uwzględni perspektywę różnych grup interesariuszy (multi-stakeholder perspective).

Zgodnie z wytycznymi IFAC zasadniczym zagadnieniem $\mathrm{w}$ procesie ustalania istotności ujawnianych kwestii jest wyznaczenie podstawowych właściwości raportowania zintegrowanego, które determinują cały proces. Należą do nich: cel jakiemu służy raport zintegrowany, jego adresaci oraz zakres raportu sformułowany w oparciu o czynniki mające wpływ na zdolność organizacji do kreowania wartości. Kolejnym krokiem jest odpowiednia selekcja istotnych kwestii. Proces ten jest opatrzony w wytycznych IFAC nazwą filtrowania tematów i składa się z trzech etapów: identyfikacji istotnych kwestii, oceny ich ważności oraz priorytetyzacji. Dopiero wtedy można rozpocząć wytyczanie granic raportowania. Chodzi tu generalnie o nakreślenie ram dla ujawnień pozafinansowych, gdyż raport zintegrowany powinien być transparentny oraz zwięzły pod względem zawartej w nim narracji, która ma uzupełnić dane i informacje finansowe.

Ciekawą ideą prezentowaną przez IFAC jest przesunięcie koncepcji raportowania zintegrowanego w obszar zarządzania, co znajduje swoje odzwierciedlenie w zaangażowaniu członków zarządu w podejmowanie decyzji dotyczących istotnych ujawnień niefinansowych. Jak wskazuje IFAC [2015], wynika to z tego, że kwestie związane z tworzeniem wartości są zazwyczaj omawiane na posiedzeniach zarządu, gdyż wiążą się ze strategią i celami organizacji oraz perspektywami jej działalności, co jest zwykle przedmiotem dyskusji podczas takich spotkań. Wskazana tendencja ma również związek z rozszerzeniem grona potencjalnych adresatów raportów zintegrowanych, które poza kapitałodawcami (inwestorami, bankami) obejmuje również interesariuszy niezaangażowanych kapitałowo, jednak powiązanych z organizacją różnymi relacjami. Przyjęcie multiperspektywicznego podejścia, które wynika z idei GRI oraz stoi w zgodzie ze standardami AA1000, wymaga od zarządzających ciągłego angażowania interesariuszy w proces doskonalenia raportowania zintegrowanego. Dzięki temu organizacja daje świadectwo otwartości na dialog oraz społecznej odpowiedzialności wobec zainteresowanych stron.

\section{Zakończenie}

W artykule porównano podejścia do zasady istotności ujawnianych kwestii, odnosząc się do regulacji obligatoryjnych oraz dobrowolnych praktyk w obszarze raportowania. 
Przeprowadzona na podstawie wytycznych i standardów analiza pozwoliła na dostrzeżenie różnic i podobieństw w pojmowaniu zasady istotności oraz procesu określania istotności (materiality determination process), co podsumowano w tabeli 2.

Tabela 2. Ujęcie zasady istotności w standardach i wytycznych raportowania niefinansowego

\begin{tabular}{|c|c|c|c|}
\hline Kategorie & Standardy GRI [2016] & $\begin{array}{c}\text { Standardy AA1000 AP } \\
{[2018]}\end{array}$ & Wytyczne IFAC [2015] \\
\hline 1 & 2 & 3 & 4 \\
\hline $\begin{array}{l}\text { Zakres } \\
\text { wpływu } \\
\text { istotnych } \\
\text { kwestii }\end{array}$ & $\begin{array}{l}\text { Wpływ na otoczenie } \\
\text { ekonomiczne, } \\
\text { środowiskowe } \\
\text { i społeczne organizacji. } \\
\text { Wpływ na oceny } \\
\text { i decyzje interesariuszy. }\end{array}$ & $\begin{array}{l}\text { Wpływ na organizację } \\
\text { (w tym na jej oceny, } \\
\text { decyzje, działania oraz } \\
\text { wyniki w krótkim, średnim } \\
\text { i długim okresie). } \\
\text { Wpływ na interesariuszy } \\
\text { (w tym na ich oceny, } \\
\text { decyzje, działania oraz } \\
\text { wyniki w krótkim, średnim } \\
\text { i długim okresie). }\end{array}$ & $\begin{array}{l}\text { Wpływ na zdolność } \\
\text { organizacji do tworzenia } \\
\text { wartości w krótkim, } \\
\text { średnim i długim okresie. }\end{array}$ \\
\hline $\begin{array}{l}\text { Typy } \\
\text { wpływu }\end{array}$ & $\begin{array}{l}\text { pozytywny, negatywny; } \\
\text { rzeczywisty, potencjalny; } \\
\text { bezpośredni, pośredni; } \\
\text { krótko-, długookresowy; } \\
\text { zamierzony, } \\
\text { niezamierzony }\end{array}$ & $\begin{array}{l}\text { bezpośredni, } \\
\text { pośredni; pozytywny, } \\
\text { negatywny; zamierzony, } \\
\text { niezamierzony; } \\
\text { oczekiwany, zrealizowany; } \\
\text { krótko-, średnio- } \\
\text { i długookresowy }\end{array}$ & $\begin{array}{l}\text { ilościowy, jakościowy; } \\
\text { finansowy, operacyjny, } \\
\text { strategiczny, związany } \\
\text { z utrzymaniem reputacji, } \\
\text { regulacyjny; wewnętrzny, } \\
\text { zewnętrzny; krótko-, } \\
\text { średnio- i długookresowy }\end{array}$ \\
\hline $\begin{array}{l}\text { Określenie } \\
\text { granic }\end{array}$ & $\begin{array}{l}\square \text { Tak, w odniesieniu do } \\
\text { istotnych kwestii. } \\
\text { Należy wskazać, w jakim } \\
\text { obszarze pojawił się } \\
\text { istotny wpływ oraz jak } \\
\text { organizacja przyczyniła } \\
\text { się do jego powstania. }\end{array}$ & $\begin{array}{l}\square \text { Tak, w odniesieniu do } \\
\text { ujawnień. } \\
\text { Wymagane jest ustalenie } \\
\text { spójnych i jasnych granic } \\
\text { ujawnień. } \\
\text { Dotyczy to granic } \\
\text { ujawnień dokonywanych } \\
\text { przez organizacje oraz } \\
\text { przez interesariuszy } \\
\text { poza procesem ich } \\
\text { zaangażowania w działania } \\
\text { spółki. }\end{array}$ & $\begin{array}{l}\square \text { Tak, w odniesieniu do } \\
\text { raportowania. } \\
\text { Proces jest dwuetapowy. } \\
\text { Najpierw bierze się pod } \\
\text { uwagę kształtowanie } \\
\text { raportu pod kątem potrzeb } \\
\text { jednostek zależnych, } \\
\text { stowarzyszonych lub } \\
\text { współpracujących } \\
\text { w ramach wspólnych } \\
\text { przedsięwzięć. } \\
\text { Następnie rozszerza się } \\
\text { granice raportowania, } \\
\text { biorąc pod uwagę } \\
\text { ryzyka, możliwości } \\
\text { oraz ewentualne skutki } \\
\text { (związane lub przypisane } \\
\text { do wskazanych } \\
\text { wyżej jednostek lub } \\
\text { interesariuszy), które mogą } \\
\text { wpływać na zdolność } \\
\text { organizacji do tworzenia } \\
\text { wartości. }\end{array}$ \\
\hline
\end{tabular}




\begin{tabular}{|l|l|l|l|}
\hline \multicolumn{1}{|c|}{2} & \multicolumn{1}{|c|}{2} & \multicolumn{1}{|c|}{3} \\
\hline $\begin{array}{l}\text { Cechy } \\
\text { procesu } \\
\text { określania } \\
\text { istotności }\end{array}$ & $\begin{array}{l}\text { Proces określania } \\
\text { istotności uwzględnia } \\
\text { wewnętrzne i zewnętrzne } \\
\text { czynniki, szersze } \\
\text { oczekiwania społeczne } \\
\text { oraz te zawarte } \\
\text { w międzynarodowych } \\
\text { standardach } \\
\text { i porozumieniach. }\end{array}$ & $\begin{array}{l}\text { Proces określania istotności } \\
\text { odnosi się do całej } \\
\text { organizacji. } \\
\text { Powinien być solidny, } \\
\text { systematyczny i ciągły. }\end{array}$ & $\begin{array}{l}\text { Proces określania istotności } \\
\text { jest specyficzny dla } \\
\text { jednostki. } \\
\text { Powinien uwzględniać } \\
\text { wpływ czynnika } \\
\text { sektorowego oraz innych } \\
\text { czynników oraz punkt } \\
\text { widzenia interesariuszy. }\end{array}$ \\
\hline $\begin{array}{l}\text { Czy } \\
\text { wskazano } \\
\text { etapy } \\
\text { procesu } \\
\text { określania } \\
\text { istotności } \\
\text { kwestii? }\end{array}$ & $\begin{array}{l}\text { ख Nie } \\
\text { Z Tak }\end{array}$ & Tak \\
\hline
\end{tabular}

Źródło: opracowanie na podstawie [GRI 2016; AA1000 AP 2018; IFAC 2015].

Różnice w percepcji istotności ujawnianych kwestii były też dostrzegane przez innych autorów [Zadek, Merme 2003]. Wskazali oni jako punkt odniesienia dla porównań trzy kryteria pojmowania istotności ujawnianych informacji. Pierwsze z nich nawiązuje do intencji, jaka przyświeca dobrowolnym ujawnieniom, stąd też kryterium to można określić jako podmiotowe. Wiąże się z nim odpowiedź na pytanie: kto jest odbiorcą istotnych informacji ujawnianych w sprawozdaniach. W tym zakresie dostrzeżono wyraźne zmiany, które polegały na rozszerzeniu grona potencjalnych adresatów sprawozdań o interesariuszy niebędących dawcami kapitału.

Drugie kryterium dotyczy przedmiotowości i jest związane z zakresem ujawnień. Zgodnie z konwencjonalną definicją istotności, kluczowymi ujawnieniami są wyniki finansowe oraz informacje, które mogą na nie wpływać w długim i krótkim okresie. W ostatnich czasach ta definicja okazała się niewystarczająca. Wraz z rozszerzeniem grona podmiotów zainteresowanych dokonaniami spółek zmieniły się wymagania co do zakresu i charakteru ujawnianych informacji. Na znaczeniu zyskały istotne aspekty pozafinansowe. Ten rodzaj ujawnień stał się ważny również w kontekście społecznie odpowiedzialnego inwestowania oraz konieczności prognozowania ryzyka finansowego, szacowania zobowiązań i określania szans związanych z ekonomicznymi, środowiskowymi i społecznymi efektami działalności.

Ostatnie kryterium dotyczy skalowalności, czyli dostosowania treści raportu do aktualnych oczekiwań i zapotrzebowania informacyjnego użytkowników. W konwencjonalnym ujęciu definicja istotności mówiła o tym, że dany fakt jest istotny, jeżeli istnieje znaczne prawdopodobieństwo, że ,rozsądny inwestor” uznałby jego pominięcie lub zniekształcenie za znacznie zmieniające cały zestaw informacji [U.S. Supreme... 1976]. Wziąwszy pod uwagę zmiany w podmiotowości i przedmiotowości pojmowania kwestii istotności ujawnianych informacji, wyraźnie widać potrzebę 
otwarcia się na głos otoczenia (interesariuszy) w dyskusji nad tym, co jest kwestią istotną, a co nie ma znaczenia dla oceny i podejmowania decyzji.

Podsumowując, należy zwrócić uwagę, iż sprawozdawczość niefinansowa, ukierunkowana na potrzeby szerokiego grona zainteresowanych stron, wymaga agregacji dużej ilości informacji. Ujawniane aspekty powinny mieć w raporcie swoje odpowiednie miejsce i formę, tak, aby wspierały proces decyzyjny zarówno organizacji, jak i interesariuszy. Ponadto ocena istotności kwestii powinna odbywać się w kontekście retrospektywnym i prospektywnym [CDP, CDSB, GRI, IFRS, IR, ISO, SASB 2016]. Stąd potrzeba włączenia procesu określania istotności do zarządzania organizacją (new materiality management). Będzie to wymagało od dyrektorów generalnych, zarządu i kierownictwa wyższego szczebla dynamicznego zaangażowania się w ten stosunkowo nowy obszar oraz ciągłego uczenia się i doskonalenia z zagadnień dotyczących ekonomicznych, środowiskowych i społecznych efektów działalności organizacji [Murninghan, Grant 2013].

\section{Literatura}

AA1000 AP, 2018, Account Ability Principles, https://www.accountability.org/standards (20.11.2018). Andriof J., Waddock S., 2002, Unfolding stakeholder engagement, [w:] Andriof J., Waddock S., Husted B., Rahma S.S. (eds), Unfolding Stakeholder Thinking, Greenleaf Publishing, Sheffield.

CDP, CDSB, GRI, IFRS, IR, ISO, SASB, 2016, Statement of common principles of materiality of the corporate reporting dialogue, https://corporatereportingdialogue.com/wp-content/uploads/ 2016/03/Statement-of-Common-Principles-of-Materiality1.pdf (1.12.2018).

Dobija D., 2010, Dylematy standaryzacji sprawozdawczości finansowej, wyceny i pomiaru ryzyka, Zeszyty Teoretyczne Rachunkowości, nr 57, s. 5-14.

FRC, 2012, Thinking about disclosures in a broader context. A road map for a disclosure framework, https:/www.frc.org.uk/consultation-list/2012/discussion-paper-thinking-about-disclosures-in-a (30.11.2018).

Freeman R.E., Harrison J.S., Wicks A.C., Parmar B., de Colle S., 2010, Stakeholder theory. The state of the art, Cambridge University Press, Cambridge.

GRI 2002, GRI G2 Sustainability Reporting Guidelines, https://www.epeat.net/documents/EPEATreferences/GRIguidelines.pdf (20.11.2018).

GRI 2006, GRI G3 Sustainability Reporting Guidelines, https://www.globalreporting.org/resourcelibrary/G3-Guidelines-Incl-Technical-Protocol.pdf (20.11.2018).

GRI 2011, GRI G3.1 Sustainability Reporting Guidelines, https://www.globalreporting.org/resourcelibrary/G3.1-Guidelines-Incl-Technical-Protocol.pdf (20.11.2018).

GRI 2013a, GRI G4 Sustainability Reporting Guidelines. Reporting Principles and Standard Disclosures, https://www.globalreporting.org/resourcelibrary/GRIG4-Part1-Reporting-Principles-andStandard-Disclosures.pdf (17.11.2018).

GRI, 2013b, GRI G4 Sustainability Reporting Guidelines. Implementation Manual, https://www. globalreporting.org/resourcelibrary/GRIG4-Part2-Implementation-Manual.pdf (17.11.2018).

GRI, 2016, Consolidated set of GRI sustainability reporting standards 2016, http://odpowiedzialnybiznes.pl/wp-content/uploads/2016/10/consolidated-set-of-gri-sustainability-reporting-standards-2016.pdf (4.02.2019).

Gruszecki T., 2002, Współczesne teorie przedsiębiorstwa, Wydawnictwo Naukowe PWN, Warszawa. 
IASB, 2018a, Definition of material (Amendments to IAS 1 and IAS 8), https://www.ifrs.org/projects/2018/definition-of-material/\#published-documents (30.11.2018).

IASB, 2018b, Conceptual Framework for Financial Reporting, March 2018, https://www.iasplus.com/ en/standards/other/framework (4.02.2018).

IFAC, 2015, Materiality in $<I R>$ Guidance for the preparation of integrated reports, November 2015, http://integratedreporting.org/wp-content/uploads/2015/11/1315_MaterialityinIR_Doc_4a_Interactive.pdf (3.02.2019).

KPMG, 2013, GRI's G4 guidelines: The impact on reporting, https://www.kpmg.com/Global/en/IssuesAndInsights/ArticlesPublications/Documents/g4-the-impact-on-reporting-v2.pdf (30.11.2018).

Marcinkowska M., 2011, Tworzenie wartości przedsiębiorstwa dla interesariuszy, Zeszyty Naukowe Uniwersytetu Szczecińskiego, nr 639, Finanse, Rynki Finansowe, Ubezpieczenia, nr 37, s. 855-869.

MSR 1, Rozporządzenie Komisji (WE) nr 1126/2008 z dnia 3.11.2008 r., przyjmujące określone międzynarodowe standardy rachunkowości zgodnie z rozporządzeniem (WE) nr 1606/2002 Parlamentu Europejskiego i Rady, Dz.Urz. UE L z 2008 r., nr 320/1 (tekst pierwotny), zmieniony przez Dz.Urz. UE L z 2017 r., nr 291/1.

MSR 8, Rozporządzenie Komisji (WE) nr 1126/2008 z dnia 3.11.2008 r. przyjmujące określone międzynarodowe standardy rachunkowości zgodnie z rozporządzeniem (WE) nr 1606/2002 Parlamentu Europejskiego i Rady, Dz.Urz. UE L z 2008 r., nr 320/1 (tekst pierwotny), zmieniony przez Dz.Urz. UE L z 2016 r., nr 323/1.

Murninghan M., Grant T., 2013, Redefining materiality II: Why it matters, who's involved, and what it means for corporate leaders and boards, AccountAbility, https://www.accountability.org/wp-content/uploads/2017/02/Redefining-Materiality-2.pdf (1.12.2018).

U.S. Supreme Court in TSC Industries v. Northway, 426 U.S. 438, 1976, https://supreme.justia.com/ cases/federal/us/426/438/ (1.12.2018).

Zadek S., Merme M., 2003, Redefining materiality. Practice and public policy for effective corporate reporting, AccountAbility, http://unpan1.un.org/intradoc/groups/public/documents/un-dpadm/ unpan044367.pdf (1.12.2018). 